Bangladesh J. Bot. 49(4): 949-956, 2020 (December)

\title{
GRANULE SIZE DISTRIBUTION AND PASTING PROPERTIES OF STARCH IN NORMAL, WAXY AND SWEET MAIZE KERNELS
}

\author{
Wenyang Li, Peijin Wu, DongPing Zhang and Suhui Yan* \\ College of Agronomy, Anhui Science and Technology University, Fengyang-233100, China
}

Keywords: Zea mays, Starch granule, Size distribution, Starch viscosity, Pasting properties

\begin{abstract}
The granule size and pasting properties of starch and their relationship with quality of maize (Zea mays L.) was investigated. A clear bimodal distribution of granule sizes was found in six cultivars of maize. A number of starch granules were made up of small starch granules in kernels. Normal maize had a smaller proportion of granules $<12 \mu \mathrm{m}$ and a greater proportion of granules $>12 \mu \mathrm{m}$, whereas sweet maize had a greater proportion of granules $<12 \mu \mathrm{m}$ and a smaller proportion of granules $>12 \mu \mathrm{m}$. The peak, trough and breakdown viscosities were found higher in waxy maize and lower in sweet maize. The final and setback viscosities were found higher in normal maize and lower in sweet maize. The peak, trough, final and setback viscosities were significantly and negatively correlated to volume percentage of granules $<12 \mu \mathrm{m}$ and significantly positively correlated with the volume percentage of granules $>12 \mu \mathrm{m}$.
\end{abstract}

\section{Introduction}

Maize (Zea mays L.) starch supplies over $80 \%$ of the world starch market, followed by potato starch (Shang et al. 2016). Starch constitutes the major carbohydrate in the endosperm of cereal grains and is deposited as discrete semi-crystalline aggregates known as starch granules in cereal endosperms (Matsushima et al. 2014, Makowska et al. 2015). Starch granules in the starch endosperm of maize, wheat and barley are in the form of single granules (Campbell et al. 1996, Ao and Jane 2007). The mean and mode of the diameter of starch granules in maize, usually discoid or lenticular in shape, are in the ranges of 16.2 - 18.2 $\mu \mathrm{m}$ and 14.2 - 16.8 $\mu \mathrm{m}$ (Campbell et al. 1996). Starch granules can be divided into large A-type and small B-type starch according to their size and shape in wheat grains (Shinde et al. 2003). The large and small starch granules have different physicochemical and functional properties (Cai et al. 2014). An increase in the rate of the small granules $(<10 \mu \mathrm{m})$ increased the farinograph water absorption and improved pasta quality in wheat (Soh et al. 2006). The differences between large and small starch granules result in the two starch granule types being used differently in industrial food and nonfood applications in cereal crops (Chen et al. 2003, Hung et al. 2006, Cui et al. 2014).

The size distribution of starch granules has a significant influence on swelling (Zhang et al. 2017), pasting (Peterson and Fulcher 2017), thermal (Ji et al. 2003), and rheological properties (Sandhu et al. 2004) in maize. Starch pasting is a process of breaking the intermolecular bonds of starch molecules in starch granules in the presence of water and heat (Zobel 1988). The pasting properties of flour are closely related to the granule size distribution of starch: large starch granules have a lower peak viscosity than small ones in wheat grains (Peterson and Fulcher 2017). The amylose content of large starch granules was significantly higher than that of small starch granules, resulting in a significant difference in starch gelatinization between the large and small starch granules in wheat (Shinde et al. 2003).

There are a few reports about the effects of cultivars on the size distribution of starch granules in normal maize (Paterson et al. 2001, Cui et al. 2014). However, little is known about the starch granule size distribution and its relationship with pasting properties in different maize cultivars

*Author for correspondence: <yansh@ahstu.edu.cn>. 
with different quality types. Therefore, the objective of this study was to investigate the starch granule size distribution and its relationship to pasting properties in maize kernels from six cultivars of normal, waxy and sweet maize.

\section{Materials and Methods}

The field experiments were carried out at the farm of Anhui Science and Technology University, Fengyang, China ( $\left.32^{\circ} 51^{\prime} \mathrm{N}, 117^{\circ} 33^{\prime} \mathrm{E}\right)$ during the maize growing seasons from June to October, 2014 and June to October, 2015. The soil was sandy loam. The average organic matter content in the tillage layer was $14.5 \mathrm{~g} / \mathrm{kg}$ and the available $\mathrm{N}$, phosphorus $(\mathrm{P})$ and potassium $(\mathrm{K})$ were $88.7,31.6$ and $68.3 \mathrm{~g} / \mathrm{kg}$, respectively. The basal fertilizer was applied at the rates of 135 $\mathrm{kg} / \mathrm{hm}^{2} \mathrm{~N}, 100 \mathrm{~kg} / \mathrm{hm}^{2} \mathrm{P}_{2} \mathrm{O}_{5}, 100 \mathrm{~kg} / \mathrm{hm}^{2} \mathrm{~K}_{2} \mathrm{O}$ before planting. A total of $135 \mathrm{~kg} / \mathrm{hm}^{2} \mathrm{~N}$ was topdressed at the booting stage of maize. The experiment was conducted as a randomized complete design with three replicates for each cultivar. The plot size was $4.8 \times 6.7 \mathrm{~m}$ with 8 rows $(60 \mathrm{~cm}$ between rows). Seeds were sown on 17 June, 2014 and 22 June, 2015 with a density of 67500 plants per $\mathrm{hm}^{2}$.

Six maize cultivars currently used in local maize production, normal maize (Zhongdan901, Longping206), waxy maize (Jingkenuo609, Fengnuo2146) and sweet maize (Wantian150, Zhongtian5), were chosen in this study. At maturity, maize kernels were dried at $60^{\circ} \mathrm{C}$ for $48 \mathrm{hrs}$ for starch granule size analysis and determination of pasting properties.

Starch was extracted from the maize cultivars according to the methods of Peng et al. (1999) with some modifications. Maize kernels $(5 \mathrm{~g})$ were steeped in $30 \mathrm{ml}$ double distilled water at $4^{\circ} \mathrm{C}$ for $24 \mathrm{hrs}$. The softened seeds were sterilized and ground with a mortar and pestle in double distilled water until essentially all the starch granules were released. The slurry was filtered through a $74 \mu \mathrm{m}$ screen and centrifuged at $1700 \times \mathrm{g}$ for $15 \mathrm{~min}$ to extract the crude starch. The crude starch was purified three times using $25 \mathrm{ml}$ of $2 \mathrm{~mol} / \mathrm{l} \mathrm{NaCl}, 0.2 \% \mathrm{NaOH}, 2 \%$ SDS and double distilled water. In addition, the starch was washed once with acetone to remove the water. Then, it was air-dried at room temperature and stored at $-40^{\circ} \mathrm{C}$.

The particle size distribution of starch was determined by using an LS13320 Laser Diffraction Particle Size Analyzer (Beckman Coulter, USA). Approximately $50 \mathrm{mg}$ of starch was suspended with $5 \mathrm{ml}$ of double distilled water in 10-ml Eppendorf tubes. After aligning the instrument and making background measurements, the starch suspension was transferred into the laser diffraction particle size analyzer's dispersion tank containing double distilled water. The starch granule size was evaluated when sufficient dispersion was added to obtain an obscuration of $8-12 \%$.

The starch pasting properties ( $3.5 \mathrm{~g}$ total weight, $14 \%$ dry basis) were measured using a rapid viscosity analyzer (RVA-Starch Master 2, Perten Instruments, Sweden) according to the methods of Lim and Seib (1993) with some modifications. A sample suspension was equilibrated at $50^{\circ} \mathrm{C}$ for $1 \mathrm{~min}$, heated to $95^{\circ} \mathrm{C}$ at $12^{\circ} \mathrm{C} / \mathrm{min}$, maintained at $95^{\circ} \mathrm{C}$ for $2.5 \mathrm{~min}$, cooled to $50^{\circ} \mathrm{C}$ at $12^{\circ} \mathrm{C} / \mathrm{min}$, and then maintained at $50^{\circ} \mathrm{C}$ for $1 \mathrm{~min}$. The paddle speed was set at $160 \mathrm{rpm}$ for starch pasting property analysis.

One-way ANOVA was performed with the SPSS statistical analysis package (SPSS Incorporated, USA). When significant treatment effects were detected, multiple comparisons among the treatments were carried out using the LSD test. Pearson's correlation coefficients were calculated to determine the relationship between the pasting properties and volume distribution of starch granules in maize kernels. The experimental data from 2015 are reported in this paper. 


\section{Results and Discussion}

The volume distribution (Fig. 1a) of starch granules showed two populations of starch granules with peak values ranging from $1.593-1.748$ and $18 \mu \mathrm{m}$ (normal maize), 1.593 and 16.4 $\mu \mathrm{m}$ (waxy maize), and $1.451-1.593$ and $8.537-9.371 \mu \mathrm{m}$ (sweet maize). The limit between the two populations occurred at approximately $2.8 \mu \mathrm{m}$. Fig. $1 \mathrm{~b}$ shows a typical population of number distribution of starch granules with peak values ranging from $0.52-0.829 \mu \mathrm{m}$ (normal maize), $0.92-0.999 \mu \mathrm{m}$ (waxy maize), and $0.52-0.755 \mu \mathrm{m}$ (sweet maize). As with the volume distribution, the surface area distribution of granules had bimodal trend with peak values ranging from $1.204-1.451$ and $16.4-18 \mu \mathrm{m}$ (normal maize), $1.322-1.451$ and $14.94-16.4 \mu \mathrm{m}$ (waxy maize) and $1.204-1.451$ and $6.453-7.776 \mu \mathrm{m}$ (sweet maize) (Fig. 1c). The limit between the populations occurred at approximately $2.8 \mu \mathrm{m}$ among the six maize cultivars.
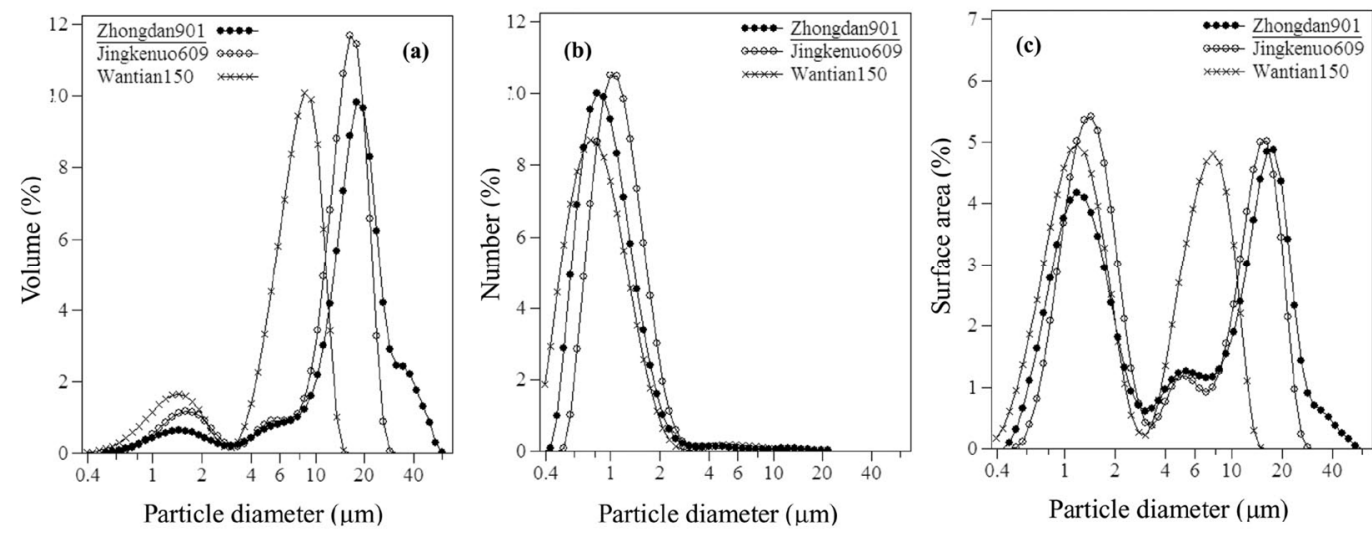

Fig. 1. Typical volume (a), number (b) and surface area (c) distribution of starch granules in maize kernels.

There are two types of starch granules in wheat grain at maturity: the large granules (generally larger than $10 \mu \mathrm{m}$ in diameter) and the small granules (smaller than $10 \mu \mathrm{m}$ in diameter) (Peng et al. 1999, Li et al. 2016). In this study, all of the maize cultivars confirmed a clearly bimodal distribution in the volume distribution, and the cutoff point for differentiating size classes of granules was approximately $2.8 \mu \mathrm{m}$. However, Ji et al. (2003) concluded that cutoff points were at 9 and $17 \mu \mathrm{m}$. This difference could be explained by different methods of calculating starch granule size or by the different maize cultivars used in each study. Starch granules were assigned to three groups according to their equivalent diameters in maize: $<2.8 \mu \mathrm{m}$ (small), $2.8-12 \mu \mathrm{m}$ (midsize), $>12 \mu \mathrm{m}$ (large) in this study.

The means of the volume percentage of starch granules $<30 \mu \mathrm{m}$ were approximately $93.17 \%$ (normal maize), $99.25 \%$ (waxy maize), and 100\% (sweet maize) of the total volume (Table 1). Contributions of the small granule population $(<2.8 \mu \mathrm{m})$ to the total volume were $7.34 \%$ (normal maize), $10.38 \%$ (waxy maize), and $16.47 \%$ (sweet maize). Variability within the starch granule population of $>2.8 \mu \mathrm{m}$ from the six cultivars was appraised by dividing the group into two regions of $2.8-12$ and $>12 \mu \mathrm{m}$. The volume percentages of granules of $2.8-12 \mu \mathrm{m}$ (midsize) were in the ranges of 15.28 (normal maize), 20.42 (waxy maize), and 66.65 (sweet maize). In addition, contributions from the starch granules $>12 \mu \mathrm{m}$ to the total volume were $77.38 \%$ (normal maize), $69.58 \%$ (waxy maize), and $16.88 \%$ (sweet maize). It showed that the proportion of granules $<12$ $\mu \mathrm{m}$ was higher in sweet maize and lower in normal maize. In addition, the proportion of granules $>12 \mu \mathrm{m}$ was higher in normal maize and lower in sweet maize. The means of the $\mathrm{D}(4,3)$ 
(weighted average volume of smaller and larger granules with weighted value of $4: 3$ ) were higher in normal maize and lower in sweet maize.

The proportions of granules $<2.8$ and $<12 \mu \mathrm{m}$ were in the range of $97-99.2$ and $99.73-$ $99.95 \%$ of the total number, respectively (Table 2), showing that a number of granules were made up of small starch granules in maize kernels. The contribution of the starch granules $<1 \mu \mathrm{m}$ to the

Table 1. Volume distribution of starch granules in maize kernels $(\%)$.

\begin{tabular}{lllllll}
\hline \multirow{2}{*}{ Types } & \multirow{2}{*}{ Cultivars } & \multicolumn{4}{c}{ Particle diameter of starch granule $(\mu \mathrm{m})$} & $\mathrm{D}(4,3)$ \\
\cline { 3 - 6 } & & $<2.8$ & $<12$ & $<20$ & $<30$ & $(\mu \mathrm{m})$ \\
\hline Normal & Zhongdan901 & $6.6 \pm 0.02 \mathrm{f}$ & $22.03 \pm 0.12 \mathrm{f}$ & $63.33 \pm 0.5 \mathrm{~d}$ & $92.57 \pm 0.06 \mathrm{~d}$ & $17.19 \pm 0.24 \mathrm{a}$ \\
maize & Longping206 & $8.07 \pm 0.03 \mathrm{e}$ & $23.2 \pm 0.1 \mathrm{e}$ & $61.8 \pm 0.3 \mathrm{e}$ & $93.77 \pm 0.06 \mathrm{c}$ & $16.98 \pm 0.02 \mathrm{a}$ \\
& Average & 7.34 & 22.62 & 62.57 & 93.17 & 17.09 \\
Waxy & Jingkenuo609 & $10.8 \pm 0.17 \mathrm{c}$ & $31.47 \pm 0.83 \mathrm{c}$ & $85.57 \pm 0.6 \mathrm{c}$ & $100 \pm 0 \mathrm{a}$ & $13.77 \pm 0.12 \mathrm{c}$ \\
maize & Fengnuo2146 & $9.96 \pm 0.21 \mathrm{~d}$ & $29.37 \pm 0.4 \mathrm{~d}$ & $86.13 \pm 0.38 \mathrm{c}$ & $98.5 \pm 0.44 \mathrm{~b}$ & $14.14 \pm 0.07 \mathrm{~b}$ \\
& Average & 1038 & 30.42 & 85.85 & 99.25 & 13.96 \\
Sweet & Wantian150 & $18.2 \pm 0.2 \mathrm{a}$ & $84.57 \pm 0.75 \mathrm{a}$ & $96.5 \pm 0.2 \mathrm{~b}$ & $100 \pm 0 \mathrm{a}$ & $7.82 \pm 0.09 \mathrm{e}$ \\
maize & Zhongtian5 & $14.73 \pm 0.15 \mathrm{~b}$ & $81.67 \pm 0.35 \mathrm{~b}$ & $97.97 \pm 0.21 \mathrm{a}$ & $100 \pm 0 \mathrm{a}$ & $8.26 \pm 0.05 \mathrm{~d}$ \\
& Average & 16.47 & 83.12 & 97.12 & 100 & 8.04 \\
F value & Cultivars & $2414.6^{* *}$ & $9971.26^{* *}$ & $4826.81^{* *}$ & $1062.08 * *$ & $3413.28 * *$ \\
\hline
\end{tabular}

Means within columns followed by different letters are significantly different at $\mathrm{p}=0.05$ according to the LSD test $(\mathrm{n}=5)$. **p $<0.01$. D $(4,3)$, weighted average volume of smaller and larger granules with weighted value of $4: 3$.

Table 2. Number distribution of starch granules in maize kernels (\%).

\begin{tabular}{|c|c|c|c|c|c|}
\hline \multirow{2}{*}{ Types } & \multirow{2}{*}{ Cultivars } & \multicolumn{4}{|c|}{ Particle diameter of starch granule $(\mu \mathrm{m})$} \\
\hline & & $<1$ & $<2.8$ & $<12$ & $>12$ \\
\hline \multirow{3}{*}{$\begin{array}{l}\text { Normal } \\
\text { maize }\end{array}$} & Zhongdan901 & $58.27 \pm 0.06 \mathrm{~d}$ & $98.2 \pm 0 \mathrm{bc}$ & $99.73 \pm 0.06 b$ & $0.27 \pm 0.06 a$ \\
\hline & Longping206 & $75.37 \pm 1.35 \mathrm{a}$ & $99.2 \pm 0 \mathrm{a}$ & $99.77 \pm 0.06 b$ & $0.23 \pm 0.06 \mathrm{a}$ \\
\hline & Average & 66.82 & 98.7 & 99.75 & 0.25 \\
\hline \multirow{3}{*}{$\begin{array}{l}\text { Waxy } \\
\text { maize }\end{array}$} & Jingkenuo609 & $39.97 \pm 0.42 \mathrm{f}$ & $98.2 \pm 0 \mathrm{bc}$ & $99.73 \pm 0.06 b$ & $0.27 \pm 0.06 \mathrm{a}$ \\
\hline & Fengnuo2146 & $46.57 \pm 1.42 \mathrm{e}$ & $98.37 \pm 0.29 b$ & $99.73 \pm 0.06 b$ & $0.27 \pm 0.06 \mathrm{a}$ \\
\hline & Average & 43.27 & 98.29 & 99.73 & 0.27 \\
\hline \multirow{3}{*}{$\begin{array}{l}\text { Sweet } \\
\text { maize }\end{array}$} & Wantian 150 & $70.47 \pm 0.55 b$ & $98.07 \pm 0.06 c$ & $99.95 \pm 0.04 \mathrm{a}$ & $0.05 \pm 0.04 b$ \\
\hline & Zhongtian5 & $61.6 \pm 2.17 \mathrm{c}$ & $97.0 \pm 0.17 \mathrm{~d}$ & $99.91 \pm 0.01 \mathrm{a}$ & $0.09 \pm 0.01 b$ \\
\hline & Average & 66.04 & 97.54 & 99.93 & 0.07 \\
\hline F value & Cultivars & $368.51 * *$ & $76.56 * *$ & $11.3 * *$ & $11.3 * *$ \\
\hline
\end{tabular}

Means within columns followed by different letters are significantly different at $\mathrm{p}=0.05$ according to the LSD test $(\mathrm{n}=5) .{ }^{* *} \mathrm{p}<0.01$.

total number was $39.97-75.37 \%$ in six maize cultivars. The variability in the starch granules among cultivars was highly significant. The percentage of the number of granules $<12 \mu \mathrm{m}$ was higher in sweet maize and lower in normal and waxy maize. In addition, the proportion of granules $>12 \mu \mathrm{m}$ was higher in normal and waxy maize and lower in sweet maize. 
Contribution of the small granules $(<2.8 \mu \mathrm{m})$ was in the ranges of $97-99.2 \%$ the total number, which showed that a number of granules were made up of small starch granules in maize kernels in this study. And contribution of granules $<2.8 \mu \mathrm{m}$ to the total volume was in the ranges of $6.6-18.2 \%$. These suggested that small starch granules possess most of the number, despite being fewer volume in compared with midsize and large starch granules in maize kernels.

The starch granules $<2.8,2.8-12$ and $>12 \mu \mathrm{m}$ occupied $45.23-56.6,17.7-44.77$ and $3.85-$ $35.7 \%$ of the total surface area among six cultivars, respectively (Table 3$)$. The means of the D (3, 2) (weighted average surface area of smaller and larger granules with weighted value of $3: 2$ ) were higher in normal maize and lower in sweet maize.

The starch pasting properties were significantly affected by maize cultivars (Table 4). The peak, trough and breakdown viscosities were higher in waxy maize and lower in sweet maize. In addition, the final and setback viscosities were higher in normal maize and lower in sweet maize. In addition, the pasting temperature was higher in sweet maize and lower in normal maize.

Waxy maize had significantly higher peak, trough, final, breakdown and setback viscosities, compared with normal maize (Sandhu et al. 2004). Singh et al. (2006) found that the starch of sweet maize could not be gelatinized under the same conditions, so the pasting parameters such as peak viscosity were lower than those of normal maize. This study showed that the peak and trough viscosities were higher in waxy maize and lower in sweet maize. The high peak viscosities of waxy maize indicated that the starch granules were harder to paste compared to normal and sweet maize. A possible explanation for this observation is that starch with high crystallinity in waxy maize exhibits high peak and breakdown viscosities (Shang et al. 2016). The final and setback

Table 3. Surface area distribution of starch granules in maize kernels (\%).

\begin{tabular}{lllllll}
\hline \multirow{2}{*}{ Types } & Cultivars & \multicolumn{2}{l}{ Particle diameter of starch granule $(\mu \mathrm{m})$} & $\mathrm{D}(3,2)$ \\
\cline { 3 - 7 } & $<1$ & $<2.8$ & $2.8-12$ & $>12$ & $(\mu \mathrm{m})$ \\
\hline Normal & Zhongdan901 & $14.0 \pm 0 \mathrm{~b}$ & $45.23 \pm 0.06 \mathrm{~d}$ & $19.07 \pm 0.06 \mathrm{c}$ & $35.7 \pm 0.1 \mathrm{a}$ & $8.95 \pm 0.01 \mathrm{a}$ \\
maize & Longping206 & $20.15 \pm 1.2 \mathrm{a}$ & $51.55 \pm 0.07 \mathrm{~b}$ & $15.7 \pm 0 \mathrm{e}$ & $32.75 \pm 0.07 \mathrm{~b}$ & $8.03 \pm 0.01 \mathrm{~b}$ \\
& Average & 17.08 & 48.39 & 17.39 & 34.23 & 8.49 \\
Waxy & Jingkenuo609 & $9.66 \pm 0.14 \mathrm{c}$ & $52.4 \pm 0.26 \mathrm{~b}$ & $18.73 \pm 0.35 \mathrm{c}$ & $28.87 \pm 0.59 \mathrm{~d}$ & $7.01 \pm 0.08 \mathrm{~d}$ \\
maize & Fengnuo2146 & $13.23 \pm 3.09 \mathrm{~b}$ & $51.8 \pm 1.47 \mathrm{~b}$ & $17.7 \pm 1.06 \mathrm{~d}$ & $30.5 \pm 0.5 \mathrm{c}$ & $7.15 \pm 0.09 \mathrm{c}$ \\
& Average & 11.45 & 52.1 & 18.22 & 29.69 & 7.08 \\
Sweet & Wantian150 & $18.37 \pm 1.25 \mathrm{a}$ & $56.6 \pm 0.3 \mathrm{a}$ & $39.57 \pm 0.06 \mathrm{~b}$ & $3.85 \pm 0.35 \mathrm{f}$ & $4.01 \pm 0.06 \mathrm{f}$ \\
maize & Zhongtian5 & $14.43 \pm 0.59 \mathrm{~b}$ & $49.77 \pm 0.38 \mathrm{c}$ & $44.77 \pm 0.32 \mathrm{a}$ & $5.47 \pm 0.12 \mathrm{e}$ & $4.58 \pm 0.03 \mathrm{e}$ \\
& Average & 16.4 & 53.19 & 42.17 & 4.66 & 4.3 \\
\hline F-value & Cultivars & $20.92^{* *}$ & $99.81^{* *}$ & $2160.16^{* *}$ & $3812.44 * *$ & $3691.06^{* *}$ \\
\hline
\end{tabular}

Means within columns followed by different letters are significantly different at $\mathrm{p}=0.05$ according to the LSD test $(\mathrm{n}=5)$. $* * \mathrm{p}<0.01$. D $(3,2)$, weighted average surface area of smaller and larger granules with weighted value of $3: 2$.

viscosities were higher in normal maize and lower in sweet maize in this study. The high final viscosities in normal maize may be because larger starch granules increase the rate of swelling and thus occupy more volume and enhance viscosity (Srichuwong et al. 2005). The pasting temperature was higher in sweet maize compared with normal and waxy maize. Peng et al. (1999) found that small starch granules had higher gelatinization peaks and completion temperatures compared to large starch granules in wheat grains. 
The pasting properties of starch, particularly the ability of starch to take up water and form a paste in the presence of heat, are affected by variations in the size distribution of starch granules (Soh et al. 2006). Peterson and Fulcher (2001) reported that large starch granules have lower peak, breakdown and setback viscosities than small ones. However, the higher average granule sizes

Table 4. The pasting properties of starch in maize kernels.

\begin{tabular}{|c|c|c|c|c|c|c|c|}
\hline Types & Cultivars & $\begin{array}{c}\text { Peak viscosity } \\
\text { (cP) }\end{array}$ & $\begin{array}{c}\text { Trough } \\
\text { viscosity }(\mathrm{cP})\end{array}$ & $\begin{array}{l}\text { Final viscosity } \\
\text { (cP) }\end{array}$ & $\begin{array}{l}\text { Breakdown } \\
\quad(\mathrm{cP})\end{array}$ & $\begin{array}{l}\text { Setback } \\
(\mathrm{cP})\end{array}$ & $\begin{array}{l}\text { Pasting } \\
\text { temp. }\left({ }^{\circ} \mathrm{C}\right)\end{array}$ \\
\hline \multirow[t]{3}{*}{$\begin{array}{l}\text { Normal } \\
\text { maize }\end{array}$} & $\begin{array}{l}\text { Zhongdan } \\
901\end{array}$ & $1424.5 \pm 2.5 \mathrm{c}$ & $865 \pm 9 c$ & $2376 \pm 78 \mathrm{a}$ & $559.5 \pm 11.5 b$ & $1511 \pm 69 a$ & $74.8 \pm 0.2 \mathrm{e}$ \\
\hline & $\begin{array}{l}\text { Longping } \\
206\end{array}$ & $1192 \pm 33 d$ & $848.3 \pm 8.5 c$ & $2293.7 \pm 27.5 a$ & $343.7 \pm 40.8 \mathrm{c}$ & $1445.3 \pm 36 a$ & $75 \pm 0.4 \mathrm{e}$ \\
\hline & Average & 1308.3 & 856.7 & 2334.9 & 451.6 & 1478.2 & 74.9 \\
\hline \multirow[t]{3}{*}{$\begin{array}{l}\text { Waxy } \\
\text { maize }\end{array}$} & $\begin{array}{l}\text { Jingkenuo } \\
609\end{array}$ & $1644 \pm 120.2 b$ & $1128 \pm 39.6 b$ & $1782 \pm 158.4 b$ & $516 \pm 80.6 b$ & $654 \pm 118.8 b$ & $76.6 \pm 0 \mathrm{~d}$ \\
\hline & $\begin{array}{l}\text { Fengnuo } \\
2146\end{array}$ & $2612.7 \pm 24.9 a$ & $1431.3 \pm 22 \mathrm{a}$ & $1783.3 \pm 14.6 b$ & $1181.3 \pm 2.9 \mathrm{a}$ & $352 \pm 9.5 c$ & $78.7 \pm 0.5 \mathrm{c}$ \\
\hline & Average & 2128.4 & 1279.7 & 1782.7 & 848.7 & 503 & 77.7 \\
\hline \multirow[t]{3}{*}{$\begin{array}{l}\text { Sweet } \\
\text { maize }\end{array}$} & $\begin{array}{l}\text { Wantian } \\
150\end{array}$ & $95 \pm 26.3 \mathrm{e}$ & $82.3 \pm 21.5 d$ & $101.3 \pm 19.7 \mathrm{c}$ & $12.7 \pm 5 d$ & $19 \pm 2 d$ & $83 \pm 0 b$ \\
\hline & Zhongtian5 & $45.5 \pm 2.5 \mathrm{e}$ & $38.5 \pm 2.5 \mathrm{e}$ & $42.5 \pm 6.5 c$ & $7.3 \pm 0.6 \mathrm{~d}$ & $4 \pm 3.5 \mathrm{~d}$ & $84.5 \pm 0.6 a$ \\
\hline & Average & 70.3 & 60.4 & 71.9 & 10 & 11.5 & 83.8 \\
\hline F value & Cultivars & $1612.8 * *$ & $3010.9 * *$ & $1001.9 * *$ & $672.1 * *$ & $619.9 * *$ & $444.2 * *$ \\
\hline
\end{tabular}

Means within columns followed by different letter are significantly different at $\mathrm{p}=0.05$ according to the LSD test $(\mathrm{n}=5) . * \mathrm{p}<0.05, * * \mathrm{p}<0.01$.

Table 5. Correlation coefficients between the pasting properties and volume distribution of starch granules in maize kernels.

\begin{tabular}{|c|c|c|c|c|c|}
\hline \multirow{2}{*}{ Items } & \multicolumn{4}{|c|}{ Volume percentage of starch granule $(\%)$} & \multirow{2}{*}{$\begin{array}{l}\mathrm{D}(4,3) \\
(\mu \mathrm{m})\end{array}$} \\
\hline & $<2.8 \mu \mathrm{m}$ & $2.8-12 \mu \mathrm{m}$ & $<12 \mu \mathrm{m}$ & $>12 \mu \mathrm{m}$ & \\
\hline Peak viscosity $(\mathrm{cP})$ & -0.6988 & $-0.8045^{*}$ & $-0.7962 *$ & $0.7962 *$ & 0.6983 \\
\hline Trough viscosity (cP) & -0.739 & $-0.8969 * *$ & $-0.8818^{* *}$ & $0.8818 * *$ & $0.7589 *$ \\
\hline Final viscosity $(\mathrm{cP})$ & $-0.9528 * *$ & $-0.9879 * *$ & $-0.9916^{* *}$ & $0.9916^{* *}$ & $0.9921 * *$ \\
\hline Breakdown (cP) & -0.6057 & -0.7289 & -0.7174 & 0.7174 & 0.5898 \\
\hline Setback (cP) & $-0.875 * *$ & $-0.7983 *$ & $-0.8168 *$ & $0.8168^{*}$ & $0.9199 * *$ \\
\hline Pasting temp. $\left({ }^{\circ} \mathrm{C}\right)$ & $0.9035 * *$ & $0.9523 * *$ & $0.9537 * *$ & $-0.9537 * *$ & $-0.9704 * *$ \\
\hline
\end{tabular}

$* \mathrm{p}<0.05 ; * * \mathrm{p}<0.01, \mathrm{D}(4,3)$, weighted average volume of smaller and larger granules with weighted value of $4: 3$.

were associated with lower values of peak and breakdown viscosities in the cocoyam (Lu et al. 2005). Small granules have lower peak and breakdown viscosities than large granules in the potato (Noda et al. 2005). The volume percentage of granules is equal to the mass percentage of granules in the case of uniform density between large and small starch granules (Peng et al. 1999, Wilson et al. 2010). In this study, correlation analysis showed that the peak, trough, final and setback 
viscosities were significantly negatively correlated to the volume percentage of granule $<12 \mu \mathrm{m}$ and significantly positively correlated to the volume percentage of granules $>12 \mu \mathrm{m}$ in maize kernels (Table 5). The $\mathrm{D}(4,3)$ had a positive correlation with pasting properties, except pasting temperature and had a significant negative correlation with pasting temperature. These suggested that large granules (larger than $12 \mu \mathrm{m}$ in diameter) have higher peak, trough, final and setback viscosities compared with small granules (smaller than $12 \mu \mathrm{m}$ in diameter) in maize starch.

\section{Acknowledgements}

This work was supported by the National Natural Science Foundation of China (31501271), the Spark Program of China (2015GA710019), the Major Natural Science Project of the Education Department in Anhui Province (KJ2020ZD010), and the Key Project of Provincial Outstanding Young Talent Foundation in Anhui Province (gxyqZD2016218).

\section{References}

Ao ZH and Jane JL 2007. Characterization and modeling of the A- and B-granule starches of wheat, triticale, and barley. Carbohyd. Polym. 67: 46-55.

Cai C, Zhao L, Huang J, Chen Y and Wei C 2014. Morphology, structure and gelatinization properties of heterogeneous starch granules from high-amylose maize. Carbohyd. Polym. 102: 606-614.

Campbell MR, Li J, Berke TG and Glover DV 1996. Variation of starch granule size in tropical maize germ plasm (1). Cereal Chem. 73: 536-538.

Chen Z, Schols HA and Voragen AGJ 2003. Starch granule size strongly determines starch noodle processing and noodle quality. J. Food Sci. 68: 1584-1589.

Cui L, Dong ST, Zhang JW and Liu P 2014. Starch granule size distribution and morphogenesis in maize (Zea mays L.) grains with different endosperm types. Aust. J. Crop Sci. 8: 1560-1565.

Hung PV, Maedac T and Morita N 2006. Waxy and high-amylose wheat starches and flours-characteristics, functionality and application. Trends Food Sci. Tech. 17: 448-456.

Ji Y, Wong K, Hasjim J, Pollak LM, Duvick S, Jane J and White PJ 2003. Structure and function of starch from advanced generations of new corn lines. Carbohyd. Polym. 54: 305-319.

Li W, Yan S, Shi X, Zhang C, Shao Q, Xu F and Wang J 2016. Starch granule size distribution from twelve wheat cultivars in east China's Huaibei region. Can. J. Plant Sci. 96: 176-182.

Lim S and Seib PA 1993. Preparation and pasting properties of wheat and corn starch phosphates. Cereal Chem. 70: 137-144.

Lu T, Chen J, Lin C and Chang Y 2005. Properties of starches from cocoyam (Xanthosoma sagittifolium) tubers planted in different seasons. Food Chem. 91: 69-77.

Makowska A, Szwengiel A, Kubiak P and Tomaszewska-Gras J 2015. Characteristics and structure of starch isolated from triticale. Starch-Stärke 66: 895-902.

Matsushima R, Maekawa M, Kusano M, Kondo H, Fujita N, Kawagoe Y and Sakamoto W 2014. Amyloplast-localized substandard starch grain 4 protein influences the size of starch grains in rice endosperm. Plant Physiol. 164: 623-636.

Noda T, Takigawa S, Matsuuraendo C, Kim SJ, Hashimoto N and Yamauchi H 2005. Physicochemical properties and amylopectin structures of large, small, and extremely small potato starch granules. Carbohyd. Polym. 60: 245-251.

Paterson JL, Hardacre A, Li P and Rao MA 2001. Rheology and granule size distribution of corn starch dispersions from two genotypes and grown in four regions. Food Hydrocolloid. 15: 453-459.

Peng M, Gao M, Abdel-Aal ESM, Huel P and Chibbar RN 1999. Separation and characterization of A- and B-type starch granules in wheat endosperm. Cereal Chem. 76: 375-379.

Peterson DG and Fulcher RG 2001. Variation in Minnesota HRS wheats: Starch granule size distribution. Food Res. Int. 34: 357-363. 
Sandhu KS, Singh N and Kaur M 2004. Characteristics of the different corn types and their grain fractions: Physicochemical, thermal, morphological, and rheological properties of starches. J. Food Eng. 64: 119-127.

Shang MS, Chen HH, Wang YS and Li QQ 2016. Effect of single and dual heat-moisture treatments on the gelatinization properties and crystalline structure of normal corn starch. Starch-Stärke 68: 1196-1202.

Shinde SV, Nelson JE and Huber KC 2003. Soft wheat starch pasting behavior in relation to A- and B-type granule content and composition. Cereal Chem. 80: 91-98.

Singh N, Inouchi N and Nishinari K 2006. Structural, thermal and viscoelastic characteristics of starches separated from normal, sugary and waxy maize. Food Hydrocolloid. 20: 923-935.

Soh HN, Sissons MJ and Turner MA 2006. Effect of starch granule size distribution and elevated amylase content on durum dough rheology and spaghetti cooking quality. Cereal Chem. 83: 513-519.

Srichuwong S, Sunarti TC, Mishima T, Isono N and Hisamatsu M 2005. Starches from different botanical sources. II: Contribution of starch structure to swelling and pasting properties. Carbohyd. Polym. 62: 25-34.

Wilson JA, Glover DV and Nyquist WE 2010. Genetic effects of the soft starch $(h)$ and background loci on volume of starch granules in five inbreds of maize. Plant Breed. 119: 173-176.

Zhang H, Zhou X, He J, Wang T, Luo X, Wang L, Wang R and Chen Z 2017. Impact of amylosucrase modification on the structural and physicochemical properties of native and acid-thinned waxy corn starch. Food Chem. 220: 413-419.

Zobel HF 1988. Starch crystal transformations and their industrial importance. Starch-Stärke 40: 1-7. 